\title{
Phenobarbital Induction of Cytochrome P-450 b,e Genes Is Dependent on Protein Synthesis
}

\author{
Jose Chianale, Leyna Mulholland, Peter G. Traber and Jorge J. Gumucio \\ Department of Medicine, Section of Gastroenterology, Veterans Administration Medical Center and the University of Michigan \\ School of Medicine, Ann Arbor, Michigan 48105
}

\begin{abstract}
Phenobarbital induces liver cytochrome $P-450$ b,e proteins mainly by increasing the rate of transcription of these genes. The mechanism responsible for the phenobarbital increment in the rate of transcription of cytochrome P-450 b,e genes is unknown. The objective of this study was to assess whether active protein synthesis was needed for phenobarbital to induce the liver cytochrome P-450 b,e genes. Cycloheximide (2 mg per kg, i.p.) was administered 90 min prior to a single inductive dose of phenobarbital (80 $\mathrm{mg}$ per $\mathrm{kg}$, i.p.) and mRNAS measured at 3,6 and 12 hr by dot-blot hybridization. While phenobarbital increased cytochrome $P-450$ b,e mRNAs about 12-fold at $3 \mathrm{hr}$, this induction was abolished by cycloheximide. To define whether the absence of protein synthesis in hepatocytes inhibited the phenobarbital induction of cytochrome $P \mathbf{- 4 5 0}$ at the transcriptional level, in vitro transcription rates using isolated nuclei were measured. After phenobarbital administration, there was about a 20-fold increment in transcriptional rate of cytochrome P-450 b,e genes. This increment was abolished by prior injection of cycloheximide. It is proposed that either preexisting regulatory proteins or transacting factors dependent on active protein synthesis participate in the regulation of liver cytochrome P-450 b,e gene transcription after phenobarbital.
\end{abstract}

Phenobarbital (PB) exerts several inductive effects on hepatocytes. Among them, the induction of various forms of cytochrome P-450 have elicited considerable interest (1). The molecular mechanism responsible for the induction of cytochrome $\mathrm{P}-450 \mathrm{~b}$,e genes by $\mathrm{PB}$, the two main components of the PB-inducible cytochrome P-450 family (1), has been defined as an increased rate of transcription of these genes in response to $\mathrm{PB}(2,3)$. However, the induction of cytochrome $\mathrm{P}-450$ proteins in response to PB occurs only in some hepatocytes. These hepatocytes are located in the distal half of the liver acinus (Zones 2 and 3), the microvascular unit of hepatic parenchyma (4-6). This heterogeneous induction of cytochrome $\mathrm{P}-450$ proteins indicated that another intraacinar level of regulation in the expression of these P-450 genes must occur. Moreover, recent studies using either isolated hepatocytes (7) or in situ hybridization (8) have

Received May 26, 1987; accepted September 8, 1987.

Address reprint requests to: Jorge J. Gumucio, M.D., Department of Medicine (111D), Veterans Administration Medical Center, 2215 Fuller Road, Ann Arbor, Michigan 48105. shown that the levels of cytochrome P-450 b,e mRNAs were induced predominantly in hepatocytes of Zones 3 and 2 of the liver acinus, respectively. However, the various intracellular events responsible for the increment in transcription rates of cytochrome P-450 b,e genes in response to $\mathrm{PB}$ have not been defined.

In this study, the objective was to determine whether active protein synthesis in hepatocytes was necessary for $\mathrm{PB}$ to induce cytochrome P-450 b,e genes. Because cycloheximide inhibited the PB-mediated induction of cytochrome P-450 b,e mRNAs in these experiments, as well as the PB increment in transcription rates in nuclear run-off studies, we propose that protein synthesis is required for the $\mathrm{PB}$-mediated induction of these genes.

\section{MATERIALS AND METHODS}

\section{Induction of Cytochrome P-450 b,e Genes}

Effect of Cycloheximide on the PB Induction of Cytochrome $P-450$ b,e mRNAs: Nonfasted Sprague-Dawley male rats weighing between 180 and $220 \mathrm{gm}$ were used in all of these experiments. Cycloheximide (Sigma Chemical Co., St. Louis, Mo.) was freshly prepared by dissolving it in $0.15 \mathrm{M} \mathrm{NaCl}$ and injected as a single dose of $2 \mathrm{mg}$ per $\mathrm{kg}$ (i.p.). Four groups of three animals each were studied. (a) Controls were injected with $0.15 \mathrm{M} \mathrm{NaCl}$. (b) PB-treated rats were injected with PB $(80 \mathrm{mg}$ per $\mathrm{kg}$, i.p.) and livers removed after 3,6 and $12 \mathrm{hr}$. (c) Cycloheximide-PB-treated rats received cycloheximide $(2 \mathrm{mg}$ per $\mathrm{kg}$, i.p.) followed $90 \mathrm{~min}$ later by $\mathrm{PB}$. This experimental design assured that PB was injected at the time of maximal inhibition of protein synthesis by this dose of cycloheximide (9). Livers were removed at 3,6 and $12 \mathrm{hr}$ after PB administration. (d) Cycloheximide-treated rats received $2 \mathrm{mg}$ per kg (i.p.) of cycloheximide only. Livers were removed after 3, 6 and 12 hr.

The NIH Guidelines for the care and treatment of laboratory animals were followed in this study.

\section{Quantitation of Cytochrome P-450 b,e mRNAs}

Extraction of RNA: Livers were frozen in liquid nitrogen and stored at $-70^{\circ} \mathrm{C}$. for 1 to 2 weeks prior to RNA extraction. Preliminary studies showed that under these conditions, there is no loss of RNA nor is there significant degradation as assessed by Northern-blot analysis. RNA was extracted from livers of each group of animals according to Chirgwin et al. (10). Only samples with a $260 / 280$ absorbance ratio above 1.8 were used.

Northern Blots: The size of the mRNA hybridizing to cytochrome P-450 b,e cDNA probes was assessed by Northern- 
blot analysis, as previously described (7). Ten micrograms of total RNA were loaded into $1 \%$ agarose gels containing $2.2 \mathrm{M}$ formaldehyde and electrophoresis performed at $5 \mathrm{~V}$ per $\mathrm{cm}$ for $4 \mathrm{hr}$. Formaldehyde-denatured RNA was transferred into nitrocellulose filters, and the filters air-dried and baked for $2 \mathrm{hr}$ at $80^{\circ} \mathrm{C}$ under vacuum. Nitrocellulose filters were prehybridized for $2 \mathrm{hr}$ at $65^{\circ} \mathrm{C}$ in a solution containing: (a) $6 \times$ standard sodium citrate $(0.9 \mathrm{M}$ sodium chloride and $0.1 \mathrm{M}$ sodium citrate); (b) $0.5 \%$ sodium dodecyl sulfate; (c) $5 \times$ Denhardt's solution (1\% Ficoll, 1\% polyvinylpyrrolidone and $1 \%$ bovine serum albumin), and (d) $100 \mu \mathrm{g}$ per ml of denatured salmon sperm DNA.

Hybridization was performed at $65^{\circ} \mathrm{C}$ for $16 \mathrm{hr}$ in a solution containing $0.9 \mathrm{M}$ sodium chloride, $0.1 \mathrm{M}$ sodium citrate, $0.5 \%$ sodium dodecyl sulfate, $5 \times$ Denhardt's solution, $0.01 M$ EDTA, $100 \mu \mathrm{g}$ per $\mathrm{ml}$ of denatured salmon sperm DNA and $25 \mathrm{ng}$ per $\mathrm{ml}$ of $\left[\alpha^{-3} \mathrm{P}\right]$-labeled cDNA insert (see next section). Filters were washed ( 7 ) and autoradiography performed at $-70^{\circ} \mathrm{C}$ using Kodak X-Omat AR film between two intensifying screens.

Quantitative Dot-Blot Hybridization: The method used was a modification of that of Papavasiliou et al. (11). A Minifold II system and nitrocellulose filters were used in these measurements. In this assay, the concentration of the cytochrome P450 b,e cDNA probes was always in excess. Each RNA sample was spotted in concentrations of $0.25,0.5,0.75,1.0,1.5$ and 2.0 $\mu \mathrm{g}$ per spot. This approach allowed the assessment of the linearity of the measurements with each sample. An internal standard, also spotted in six concentrations, was always included in each new filter to assess the reproducibility of the spotting and blotting procedure as well as the efficiency of hybridization. This internal standard consisted of RNA extracted from a PB-treated liver and stored at $-70^{\circ} \mathrm{C}$. The quality of this RNA serving as a standard was assessed periodically by Northern-blot analysis and quantitated by dot-blot hybridization as described here. This allowed the comparison of the slopes of the lines obtained with each filter. After hybridization, the filters were washed (7), autoradiography performed and ${ }^{32} \mathrm{P}$-cpm in each spot counted. For this purpose, the nitrocellulose paper was cut-off in each spot while background radioactivity was assessed by counting a cut-off of nitrocellulose paper in which RNA had not been spotted. Nonspecific hybridization was assessed by spotting pBR322. Results have been expressed as cpm bound per microgram of RNA (11).

Preparation of the cDNA Probe: The cytochrome P-450 b,e probe used in these experiments was a generous gift from Dr. M. Adesnik (New York University). This clone (R17) consists of a 1,100 b.p. cDNA cloned into pBR322. This cDNA codes for 211 amino acids of the $3^{\prime}$-carboxyterminal end of a polypeptide corresponding to cytochrome $P-450$ e (12). Due to the extensive homology between cytochrome $P-450$ b,e genes (13), this cDNA recognizes sequences of both cytochrome $P-450 \mathrm{~b}, \mathrm{e}$ mRNAs. In this study, the measured levels of cytochrome P$450 \mathrm{mRNA}$ have been expressed as if both cytochromes were assessed simultaneously. Accordingly, measurements have been described in the text as "cytochrome P-450 b,e mRNAs."

The cDNA was isolated from R17 by agarose gel electrophoresis and electroblotting onto DEAE membranes (Schleicher and Schuell, Keene, NH) and was labeled with $\left[{ }^{32} \mathrm{P}\right] \mathrm{dATP}$ (Amersham Corp., Arlington Heights, Ill.; 3,000 Ci per mmole) by the "oligolabeling" method [large fragment (Klenow) of DNA polymerase I, BRL, Gaithersburg, Md.] of Feinberg and Vogelstein (14).

To assess the specificity of the effects of cycloheximide on cytochrome P-450 genes, levels of albumin mRNA were determined using the same RNA samples in which cytochrome $P$ 450 mRNA measurements were performed. Thus, albumin mRNA levels were assessed in control, PB-treated and cyclo-
heximide-PB-treated rats. These measurements were performed as previously described, except that the cDNA probe used was pmalb 2, a generous gift from Drs. S. Tilghman and Belayew (15). The cDNA insert was isolated and labeled with $\left[{ }^{32} \mathrm{P}\right] \mathrm{dATP}$ by the oligolabeling method (14).

\section{In Vitro Transcription Rates: Nuclear Run-Off Assay}

Animal Preparation: Male Sprague-Dawley rats weighing 180 to $200 \mathrm{gm}$ were used in these experiments. Four groups of four animals each were studied: (a) controls (C), who were injected with $0.15 M \mathrm{NaCl}$, i.p.; (b) PB-treated rats received 80 mg per kg (i.p.) PB and were studied $3 \mathrm{hr}$ later; (c) cycloheximide-treated rats received $2 \mathrm{mg}$ per $\mathrm{kg}$ (i.p.) and experiments were performed $3 \mathrm{hr}$ later, and (d) cycloheximide-PB-treated rats received $2 \mathrm{mg}$ per $\mathrm{kg}$ (i.p.) cycloheximide followed $90 \mathrm{~min}$ later by $80 \mathrm{mg}$ per $\mathrm{kg}$ (i.p.) PB. Experiments were performed 3 hr after PB injection.

Preparation of Isolated Nuclei: Nuclei were isolated according to Schibler et al. (16) with few modifications. Livers were homogenized in 20 volumes $0.3 M$ sucrose in buffer A [ $60 \mathrm{mM}$ $\mathrm{KCl}, 15 \mathrm{~m} M \mathrm{NaCl}, 0.15 \mathrm{~m} M$ spermin, $0.5 \mathrm{~m} M$ spermidine, 14 $\mathrm{m} M \beta$-mercaptoethanol, $0.5 \mathrm{~m} M$ EGTA, $2 \mathrm{~m} M$ EDTA, $15 \mathrm{~m} M$ Hepes ( $\mathrm{pH} 7.5)$. The homogenate was filtered through nylon cloth (mesh width $=100 \mu \mathrm{m}$ ), layered over a $10 \mathrm{ml}$ cushion of $30 \%$ sucrose in buffer $A$ and spun for $10 \mathrm{~min}$ at $2,500 \mathrm{rpm}$ in a SS 34 rotor (Sorvall). Crude nuclei were resuspended in $42 \mathrm{ml}$ $2 M$ sucrose in buffer B (prepared as buffer A except, that 0.1 $\mathrm{m} M$ EGTA and $0.1 \mathrm{~m} M$ EDTA were used) and centrifuged at $36,000 \mathrm{rpm}$ for $30 \mathrm{~min}$ at $4^{\circ} \mathrm{C}$ in an SW 41 rotor (Beckman L2$65 \mathrm{~B}$ centrifuge). The clean nuclei were sedimented in nuclei storage buffer [20 mM Tris-HCl ( $\mathrm{pH} 7.9$ ), $75 \mathrm{mM} \mathrm{NaCl}, 0.5$ $\mathrm{m} M \mathrm{Na}_{2}$ EDTA, $0.85 \mathrm{~m} M$ dithiothreitol, $50 \%$ (v:v) glycerol]. The nuclear pellet was resuspended in nuclei storage buffer at a concentration of $10^{6}$ nuclei per $\mu$ l of nuclei storage buffer. Nuclei were stored at $-70^{\circ} \mathrm{C}$ for $24 \mathrm{hr}$ before use.

In Vitro Transcription Assay: The transcription reaction was performed according to Love et al. (17). The transcription reaction was initiated by adding $3 \times 10^{8}$ nuclei $(300 \mu \mathrm{l})$ to 300 $\mu \mathrm{l}$ of the transcription assay solution [ATP, GTP, CTP, $1 \mathrm{mM}$ each; $4.4 \mathrm{mM}$ magnesium acetate, $1.7 \mathrm{mM} \mathrm{MnCl}_{2}, 7.15 \mathrm{mM}$ Tris (pH 8.0); $1.43 \mathrm{M} \mathrm{KCl} ; 500 \mu \mathrm{Ci}\left[\alpha{ }^{32} \mathrm{P}\right] \mathrm{UTP}$ (400 Ci per mmole; Amersham Corp.)]. The final concentration of $\left[\alpha^{-32} \mathrm{P}\right]$ UTP in the reaction was $2.08 \mu M$. The assay was performed at $23^{\circ} \mathrm{C}$ for $30 \mathrm{~min}$. The reaction was terminated by addition of 4 $M$ guanidinium thiocyanate solution [ $50 \mathrm{mM}$ sodium citrate, $130 \mathrm{~m} M \beta$-mercaptoethanol, $2 \%$ sarcosyl, $10 \mathrm{mM}$ EDTA (pH 8.0)]. The RNA transcripts were purified in a $\mathrm{CsCl}_{2}$ gradient according to Love et al. (17).

Assessment of Transcripts: The elongation of nascent RNA chains or transcripts was measured by hybridization of the ${ }^{32}$ P]RNA transcripts generated in the transcription reaction to nylon membranes (Nytran ${ }^{\circledR}$, Schleicher and Schuell) containing the cytochrome P-450 cDNA probe. In these experiments, the cytochrome P-450 b,e cDNA was isolated from the $\mathrm{R} 17$ clone as previously described and cloned into the pGem-1 riboprobe. Northern-blot analysis (not shown here) showed that this pGem-1 containing the cytochrome P-450 cDNA hybridized to a mRNA of identical size as that hybridized by the cDNA insert (shown in Figure 1). The pGem-1-cytochrome P-450 b,e cDNA plasmid was linearized (HindIII), denatured in $0.5 \mathrm{~N} \mathrm{NaOH}: 1.5 \mathrm{M} \mathrm{NaCl}$ and $100 \mathrm{ng}$ (concentration determined by measuring the $260 \mathrm{~nm}$ absorbance) blotted onto nylon membranes using a Minifold II apparatus. The method of hybridization used was that of Church and Gilbert (18). Hybridization was performed at $65^{\circ} \mathrm{C}$ for $18 \mathrm{hr}$. Each hybridization was performed using $4 \mathrm{ml}$ hybridization buffer, a $6.2 \times 2.8 \mathrm{~cm}$ nylon membrane and $1 \times 10^{7} \mathrm{cpm}$ per $\mathrm{ml}$. At the end of the 


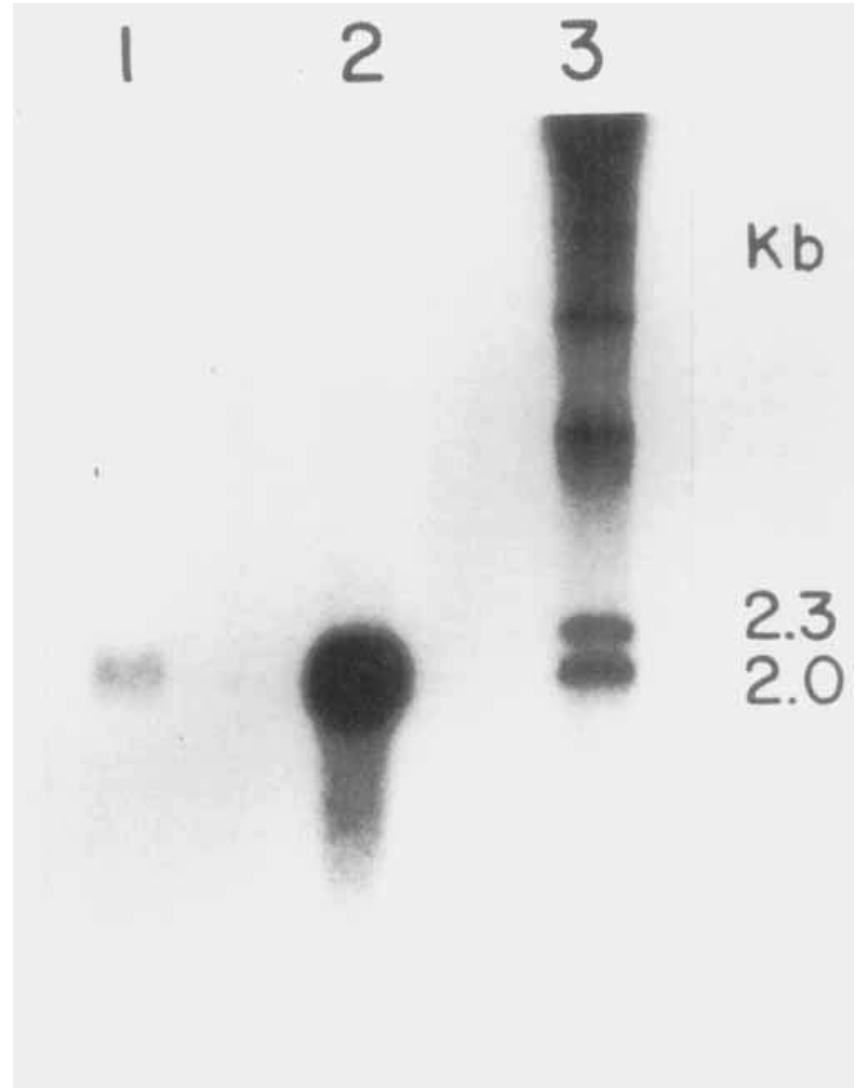

Fig. 1. Northern-blot analysis of cytochrome P-450 b,e mRNAs. (Lane 1) Control; $10 \mu \mathrm{g}$ RNA loaded. (Lane 2) PB-induced; RNA extracted $16 \mathrm{hr}$ after a single dose of PB (80 mg per $\mathrm{kg}$, i.p.); $10 \mu \mathrm{g}$ RNA loaded. (Lane 3) $\lambda$-size markers (HindIII digest).

hybridization, the filters were washed (18) and autoradiography performed. Background hybridization was assessed by using pGem-1 plasmid without the cDNA insert.

\section{RESULTS}

The effect of blocking protein synthesis at the translational level by cycloheximide on the increments in cytochromes P-450 b,e mRNAs by PB was studied. In these experiments, cycloheximide was injected $(2 \mathrm{mg}$ per $\mathrm{kg}$, i.p.) followed $90 \mathrm{~min}$ later by the administration of PB ( $80 \mathrm{mg}$ per kg, i.p.). It should be noted that maximal inhibition of protein synthesis (by at least $80 \%$ ) has been observed with this dose of cycloheximide $(9,19)$. Figure

FIG. 2. Cytochrome P-450 b,e mRNAs. Effect of cycloheximide. (a) Dot-blot analysis. Controls $=$ injected with $0.15 \mathrm{M} \mathrm{NaCl} ; \mathrm{PB}=\mathrm{PB}-$ treated $(80 \mathrm{mg}$ per $\mathrm{kg}$, i.p.); $\mathrm{Cx}-\mathrm{PB}=$ cycloheximide $(2 \mathrm{mg}$ per $\mathrm{kg}$, i.p.) followed $90 \mathrm{~min}$ later by $\mathrm{PB}(80 \mathrm{mg}$ per $\mathrm{kg}$, i.p.); $\mathrm{Cx}=$ cycloheximide ( $2 \mathrm{mg}$ per $\mathrm{kg}$, i.p.). Numbers at the right-hand side of the abbreviation for each group indicate the time interval (in hours) between the injection and the removal of the liver. In $\mathrm{Cx}-\mathrm{PB}$, it indicates time after PB administration. At the bottom, the amount of RNA spotted in each slot is indicated. Each sample was analyzed in six different concentrations. The raw data obtained after $6 \mathrm{hr}$ are not shown. (b) The same data calculated as cpm DNA bound per microgram of RNA spotted. Mean \pm S.E. of three animals per group. Livers were removed after 3, 6 and $12 \mathrm{hr}$ of the PB injection. Dotted bars = cytochrome $\mathrm{P}-450 \mathrm{~b}, \mathrm{e}$ mRNAs after PB administration. Solid bars $=$ cytochrome P-450 b,e mRNAs after PB injection preceded, 90 min earlier, by cycloheximide administration.
1 shows that, by Northern-blot analysis, the $\left[{ }^{32} \mathrm{P}\right]$ cytochrome $\mathrm{P}-450 \mathrm{cDNA}$ probe used in these experiments hybridized to a mRNA of about $2.1 \mathrm{~kb}$. This corresponds to the size of mRNAs previously reported for cytochromes P-450 b,e mRNAs (1). Figure 2a shows the results of the quantitative dot-blot analysis. The autoradiography corresponding only to the samples obtained
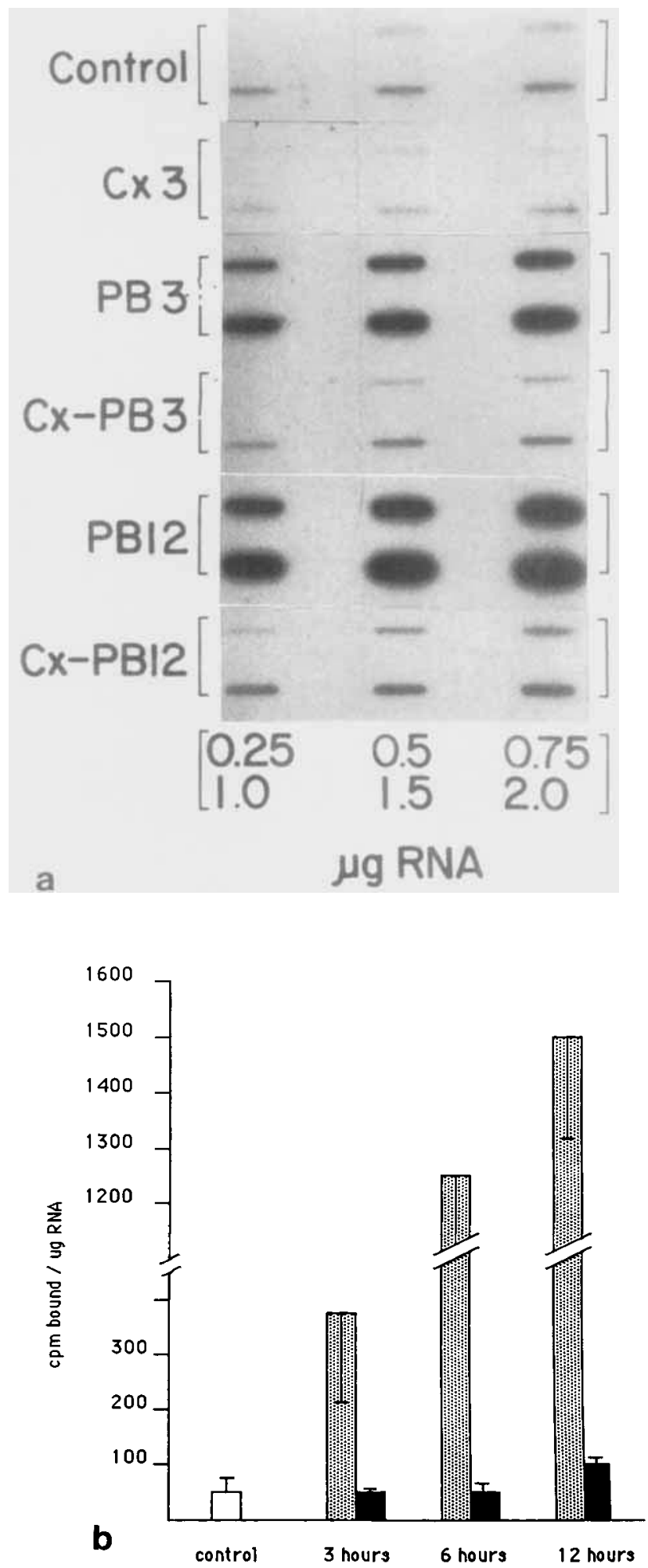
at 3 and $12 \mathrm{hr}$ is shown. An entirely similar resolution was obtained with all samples analyzed. Quantitation of dot-blots is presented in Figure 2b. In this figure, results have been expressed as cpm per microgram of RNA spotted. When PB was injected alone, the levels of cytochrome P-450 b,e mRNAs increased about 10 -fold at 3 $\mathrm{hr}$ and about 30-fold by $12 \mathrm{hr}$. Cycloheximide injected 90 min before $\mathrm{PB}$ administration abolished the induction of the cytochrome P- 450 b,e mRNAs. Cycloheximide was injected alone in two experiments, and RNA was extracted at 3,6 and $12 \mathrm{hr}$. The levels of cytochrome P-450 b,e mRNAs were low (results not shown) and apparently lower than in controls. However, given the low levels of expression of the cytochrome P-450 b,e genes in controls, it became apparent that many more experiments would be needed to ascertain whether the constitutive expression of these genes was influenced by cycloheximide. This was not the purpose of these studies. To assess the specificity of these results, the effects of cycloheximide on the levels of albumin mRNA were determined using the same RNA in which cytochrome P-450 was measured. Figure 3 shows that albumin mRNA levels were not influenced by cycloheximide administration at the time intervals studied.

To assess whether this inhibitory effect of cycloheximide on cytochrome P-450 b,e induction by PB was exerted at the level of the transcription of these genes, in vitro transcription assays were performed. Figure 4 shows the autoradiography of a representative experiment involving the measurements of in vitro transcription in each of the four groups (control, cycloheximide, cycloheximide- $\mathrm{PB}$ and $\mathrm{PB}$ alone). The hybridization signals of controls and after cycloheximide alone were faint. In contrast, $3 \mathrm{hr}$ after the administration of $\mathrm{PB}$, there was about a 20 -fold increment in the rate of in vitro transcription of the cytochrome P-450 b,e genes. Cycloheximide, injected $90 \mathrm{~min}$ before $\mathrm{PB}$, inhibited the $\mathrm{PB}$ -

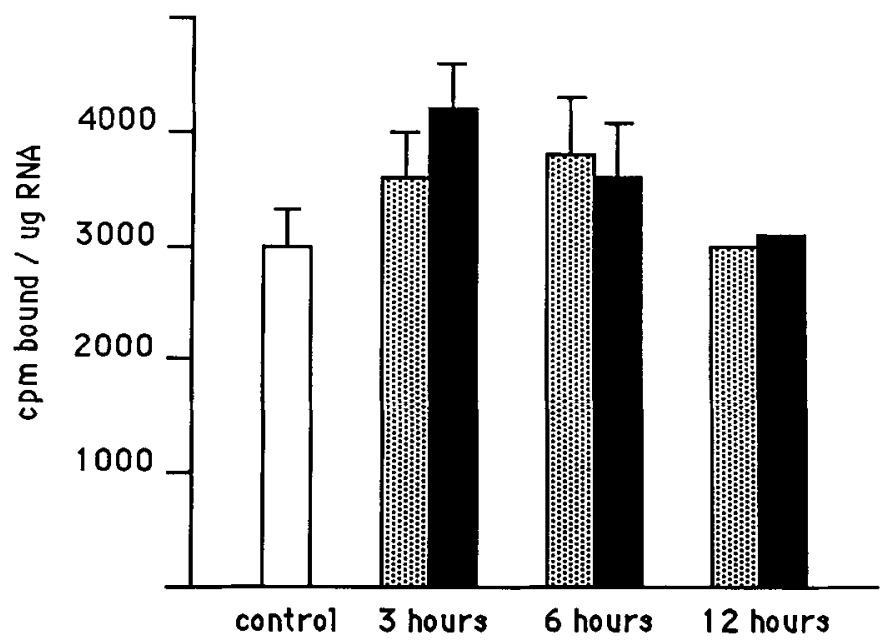

FIG. 3. Effect of cycloheximide on albumin mRNA levels. Albumin mRNA levels were assessed using the same RNA samples obtained from controls, $\mathrm{PB}$-treated and cycloheximide-PB-treated rats described in Figure 2 ( $a$ and $b$ ). The albumin cDNA insert was isolated and labeled with $\left[{ }^{32} \mathrm{P}\right] \mathrm{dATP}$ by the oligolabeling method (14). Dotted bars $=$ albumin mRNA after $\mathbf{P B}$ administration. Solid bars = albumin mRNA after PB preceded, 90 min earlier, by the administration of cycloheximide. Mean \pm S.E. of three animals per group except the point at $12 \mathrm{hr}$ in which only two samples were measured. induced increment in the rate of in vitro transcription. A total of five experiments measuring in vitro transcription in each of the four groups studied were performed. All experiments showed similar results. Cycloheximide always blocked the induction of cytochrome P-450 b,e genes by $\mathrm{PB}$.

\section{DISCUSSION}

The aim of this study was to determine whether active protein synthesis in hepatocytes was required for the induction of cytochrome P-450 b,e genes in response to $\mathrm{PB}$. This represents an initial approach to elucidate the molecular mechanisms leading to the transcriptional induction of these genes.

Cycloheximide has been used in several studies in an attempt to answer whether the rate of protein synthesis influences the expression or the induction of genes (1923). The possibility that cycloheximide may indiscriminately depress gene activity by decreasing RNA polymerase II is unlikely. Following cycloheximide administration, measurements of RNA polymerase II activity have indicated that the activity of this enzyme is increased (20). Moreover, induction of certain genes to levels higher than those observed with the inducer alone or "superinduction" has been reported after cycloheximide administration (21). Such an example is the superinduction of cytochrome $\mathrm{P}_{1}-450$ (representative of a different family of P-450 than P-450 b or e) in the presence of cycloheximide and the inducer 2,3,7,8-tetrachlorodibenzo-p-dioxin in mouse hepatoma cells (21). Under these conditions, the induction of the $\mathrm{P}_{1}-450$ gene is 10 -fold higher than in the presence of the inducer alone. Therefore, the effect of cycloheximide on gene expression appears to be selective and, accordingly, the regulation of genes can be separated into those dependent on, or independent of, protein synthesis $(19,22-23)$. Moreover, similar responses of genes have been observed when other agents blocking protein synthesis at a translational level, such as emetine, have been used (19). These observations suggest that, in these experiments, cycloheximide was acting in its capacity to inhibit protein synthesis rather than in a nonspecific manner.

In this study, PB was injected in vivo at the time of maximal inhibition of protein synthesis by cycloheximide $(9,19)$. Cycloheximide blocked the induction of cytochrome P-450 b,e mRNAs by PB. In contrast, the levels of albumin mRNA were not affected within the time interval of these experiments. The mechanism of this apparent difference in the response of cytochrome P-450 b,e genes and of the albumin gene to cycloheximide needs further study.

The nuclear run-off studies indicated that the molecular mechanism responsible for the inhibition of the PBmediated induction of cytochromes P-450 b,e genes is the inability of $P B$ to increase the transcription rates of these genes in the absence of active protein synthesis in hepatocytes. These observations suggest that a protein(s), either present at the time of $\mathrm{PB}$ administration or synthesized in response to $\mathrm{PB}$, modulates the induction of the cytochrome P-450 b,e genes by activating (or derepressing) the rate of transcription of these genes. If 


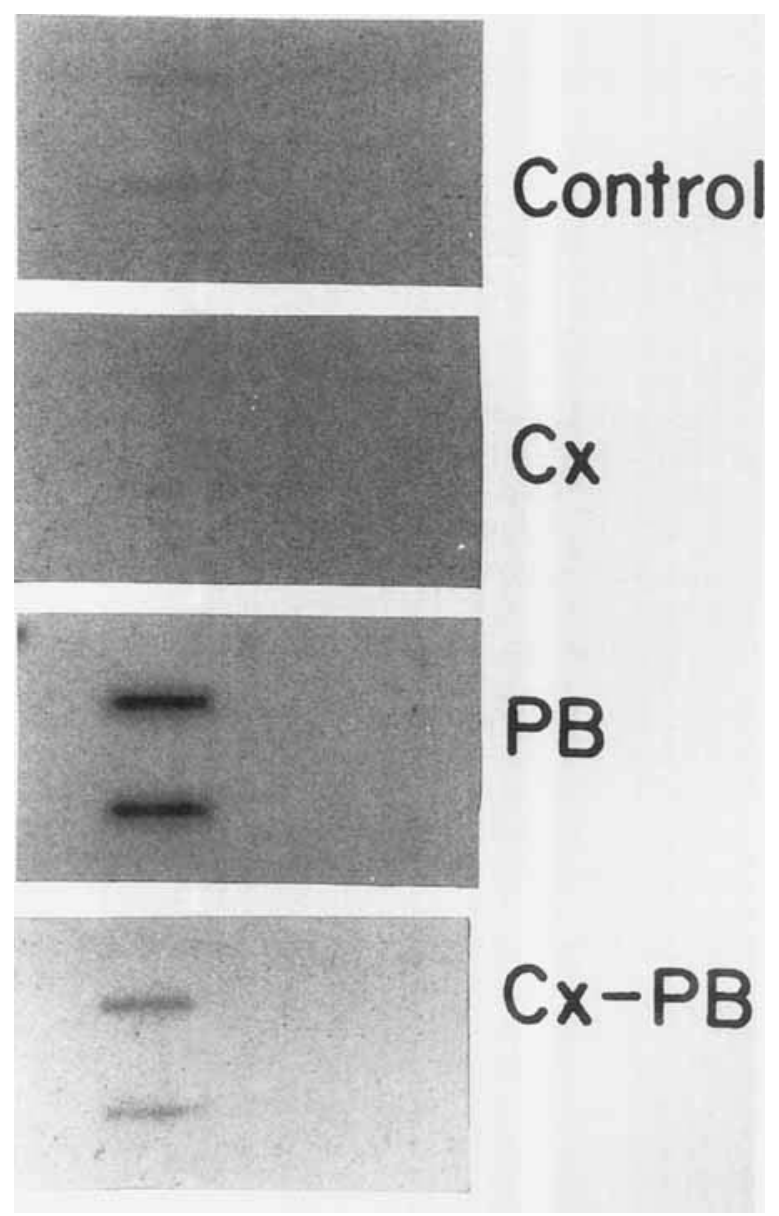

Fig. 4. In vitro transcription assay of cytochrome $P-450$ b,e genes using isolated liver nuclei. Controls, cycloheximide $(\mathrm{Cx}), \mathrm{PB}$ and $\mathrm{Cx}-$ PB groups were prepared as described in the legend to Fig. 2. In these experiments, nuclei were isolated $3 \mathrm{hr}$ after injections (in $\mathrm{Cx}-\mathrm{PB}, 3 \mathrm{hr}$ after $\mathrm{PB}$ administration). RNA transcripts generated in each transcription assay were hybridized against duplicate blots containing $100 \mathrm{ng}$ pGem-1 cytochrome P-450 cDNA insert isolated from R17. This is one representative sample of five individual experiments in each group. In each experiment, cycloheximide blocked almost completely the increment in transcription observed after $\mathrm{PB}$. The mean difference in transcription signals between $\mathrm{PB}$ and $\mathrm{Cx}-\mathrm{PB}$ assessed by densitometric analysis was 11-fold. This autoradiography was exposed for $72 \mathrm{hr}$.

the regulatory protein is preexisting in the cytoplasm or nucleus of hepatocytes, it must have a relatively short half-life to account for the observed results. Therefore, we propose that transacting regulatory proteins participate in the modulation of the rate of transcription of the liver cytochrome $\mathrm{P}-450 \mathrm{~b}, \mathrm{e}$ genes in response to $\mathrm{PB}$ administration.

\section{REFERENCES}

1. Adesnik M, Atchison M. Genes for cytochrome P-450 and their regulation. Crit Rev Biochem 1986; 19:247-305.

2. Hardwick JP, Gonzalez FJ, Kasper C. Transcriptional regulation of rat liver epoxide hydratase, NADPH-cytochrome P-450 oxidoreductase, and cytochrome $\mathrm{P}-450 \mathrm{~b}$ genes by phenobarbital. J Biol Chem 1983; 258:8081-8085.

3. Atchison M, Adesnik M. A cytochrome P-450 multigene family. J Biol Chem 1983; 258:11285-11295.

4. Gooding PE, Chayen J, Sawyer BN, et al. Cytochrome P-450 distribution in rat liver and the effect of sodium phenobarbitone administration. Chem-Biol Interact 1978; 20:299-310.

5. Baron J, Redick JA, Guengerich FP. An immunohistochemical study on the localizations and distributions of phenobarbital- and 3-methylcholanthrene-inducible cytochrome P-450 within the livers of untreated rats. J Biol Chem 1981; 256:5931-5937.

6. Ohnishi K, Mishima A, Okuda K. Immunofluorescence of phenobarbital inducible cytochrome P-450 in the hepatic lobule of normal and phenobarbital treated rats. Hepatology 1982; 2:849-855.

7. Chianale J, Dvorak C, May M, et al. Heterogeneous expression of phenobarbital-inducible cytochrome P-450 genes within the hepatic acinus in the rat. Hepatology 1986; 6:945-951.

8. Gumucio JJ, Wojcik E, Traber PG, et al. Molecular mechanism of the heterogeneous induction of cytochrome $\mathrm{P}-450$ by phenobarbital within the liver acinus. A transcriptional event (Abstract). Gastroenterology 1987; 92:1419.

9. Rothblum LI, Devlin TM, Ch'ih JJ. Regulation of mammalian protein synthesis in vivo. Biochem $J$ 1976; 156:151-157.

10. Chirgwin JM, Przybyla AE, MacDonald RJ, et al. Isolation of biologically active ribonucleic acid from sources enriched in ribonuclease. Biochemistry 1979; 18:5294-5299.

11. Papavasiliou SS, Zmeili S, Herbon L, et al. Alpha and luteinizing hormone beta messenger ribonucleic acid (RNA) of male and female rats after castration: quantitation using an optimized RNA dot blot hybridization assay. Endocrinology 1986; 119:691-697.

12. Kumar A, Raphael C, Adesnick M. Cloned cytochrome P-450 cDNA. J Biol Chem 1983; 258:11280-11284.

13. Suwa Y, Mizukami Y, Sogawa K, et al. Gene structure of a major form of phenobarbital-inducible cytochrome P-450 in rat liver. $J$ Biol Chem 1985; 260:7980-7984.

14. Feinberg AP, Vogelstein B. Technique for radiolabeling DNA restriction endonuclease fragments to high specific activity. Anal Biochem 1983; 132:6-13.

15. Tilghman SM, Belayew A. Transcriptional control of the murine albumin/alpha-fetoprotein locus during development. Proc Natl Acad Sci USA 1982; 79:5254-5257.

16. Schibler V, Hagenbuche O, Wellauer PK, et al. Two promoters of different strengths control the transcription of the mouse alphaamylase gene Amy-1 in the parotid gland and the liver. Cell 1983; 33:501-508.

17. Love JD, Vivino AA, Minton KW. Detection of low-level gene induction using in vitro transcription. Gene Anal Tech 1985; 2:100107.

18. Church GM, Gilbert W. Genomic sequencing. Proc Natl Acad Sci USA 1984; 81:1991-1995.

19. Jacoby DB, Engle JA, Towle HC. Induction of a rapidly responsive gene product by thyroid hormone requires ongoing protein synthesis. Molec Cell Biol 1987; 7:1352-1357.

20. Lindell TJ, Duffy JJ. Enhanced transcription by RNA polymerases II and III after inhibition of protein synthesis. J Biol Chem 1979; 254:1454-1456.

21. Israel DI, Estolano MG, Galeazzi DR, et al. Superinduction of cytochrome P-450 gene transcription by inhibition of protein synthesis in wild type and variant mouse hepatoma cells. J Biol Chem $1985 ; 260: 5648-5653$.

22. Greenberg ME, Hermanowski AL, Ziff EB. Effect of protein synthesis inhibitors on growth factor activation of c-fos, c-myc and actin gene transcription. Molec Cell Biol 1986; 6:1050-1057.

23. Widelitz RB, Magun BE, Gerner EW. Effects of cycloheximide on thermotolerance expression, heat shock protein synthesis, and heat shock protein mRNA accumulation in rat fibroblasts. Molec Cell Biol 1986; 1088-1094. 